\title{
Early Initiation and Prevalence of Exclusive Breastfeeding: A Cross-sectional Study among Employed Mothers in Bantul District, Indonesia
}

\section{Mia Ervina ${ }^{1}$, Bunga Astria Paramashanti ${ }^{1}$, Hamam Hadi ${ }^{1}$ and Nur Indah Rahmawati $^{2}$}

\author{
${ }^{1}$ Department of Nutrition, Faculty of Health Sciences, Universitas Alma Ata, Yogyakarta 55183, Indonesia \\ ${ }^{2}$ Department of Midwifery, Faculty of Health Sciences, Universitas Alma Ata, Yogyakarta 55183, \\ Indonesia
}

\section{Correspondence: \\ Bunga Astria Paramashanti \\ Universitas Alma Ata Jalan Brawijaya \\ No. 99 \\ Kasihan, Bantul, \\ Daerah Istimewa Yogyakarta, 55183, Indonesia \\ Email: bunga@almaata.ac.id}

DOI: $10.3126 /$ jnps.v40i3.29907

Submitted on: 2020-05-11

Accepted on: 2020-06-19

Acknowledgements: We gratefully thank the participants in nine limited liability companies (PT. Cahaya Mulia Persada, PT. Dong Young Tress Indonesia, PT. IGP International, PT. Marvel Sport Indonesia, PT. Samku Glove Indonesia, PT. Yogyakarta Tembakau, PT. Dagsap Endura Eatur, PT. Merapi Agung Lestari, and CV. Ide Studio) who took part in the present study.

Funding: Nil

Conflict of Interest: None declared Permission from IRB: Yes

To cite this article: Ervina $M$, Paramashanti BA, Hadi H, Rahmawati NI. Neonatal Outcome of Macrosomia. J Nepal Paediatr Soc. 2020;40(3):190-6.

\begin{abstract}
Introduction: Exclusive breastfeeding plays an important role in preventing morbidity and mortality in infants and young children. However, exclusive breastfeeding coverage remains low, especially among working mothers. This study aimed to examine the relationship between early initiation of breastfeeding and prevalence of exclusive breastfeeding among working mothers in Bantul District, Yogyakarta Special Region, Indonesia.
\end{abstract}

Methods: This study used a cross-sectional design. The population were all women in reproductive age who worked in middle and large companies. Samples included mothers whose infants were aged six to 12 months and were selected by probability proportional to size sampling technique. Main outcome was exclusive breastfeeding, while the independent variable was the early initiation of breastfeeding. Statistical analysis were descriptive statistics test, chi-square test, and multiple logistic regression at the level of significance of 0.05 .

Results: Exclusive breastfeeding coverage was around $22 \%$, whilst the early initiation of breastfeeding coverage was $10 \%$. Early initiation of breastfeeding was associated with exclusive breastfeeding practice (adjusted OR $=2.93 ; 95 \%$ CI: $1.04-8.28$ ). Variables that were not significantly related to exclusive breastfeeding included being a firsttime mother, maternal age, maternal educational level, breastfeeding counselling during antenatal visits, and delivery methods.

Conclusions: Early initiation of breastfeeding is associated with higher prevalence of exclusive breastfeeding among working mothers. To increase exclusive breastfeeding coverage, particularly among employed women, it is highly recommended to enhance early initiation of breastfeeding program.

Key words: early initiation of breastfeeding; employed mothers; exclusive breastfeeding; Indonesia; working mothers

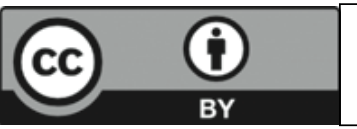

This work is licensed under creative common attribution 3.0 license 


\section{INTRODUCTION}

Based on the 2017 Indonesian Demographic Health Survey, the infant mortality rate in Indonesia is 24 per 1,000 live births which is remarkably higher. ${ }^{1}$ In order to reduce infant mortality and morbidity, UNICEF and WHO recommend providing exclusive breast feeding during the first six months of life and continued breastfeeding up to two years of age. ${ }^{2}$ Exclusive breastfeeding is defined as providing only breast milk without additional food or liquid, including water. Breast milk has important benefits that is known to protect infants from infectious illnesses and chronic diseases, help infant's recovery after illness, as well as reducing overall infant morbidity and mortality. In mothers, exclusive breastfeeding is associated with a lower chance of following pregnancy and decreased risk of breast and cervix cancers. ${ }^{3}$

Exclusive breastfeeding coverage in Indonesia was $55.7 \%$, whereas the national target is $80 \% .{ }^{4}$ Various earlier studies in Indonesia have reported variable exclusive breastfeeding proportions in different regions. ${ }^{5,6}$ One of the national efforts to improve exclusive breastfeeding coverage is through early initiation of breastfeeding program. ${ }^{7}$ Early initiation of breastfeeding means breastfeeding within the first hour of birth. ${ }^{8}$ In Indonesia, early initiation of breastfeeding remained low, ranging from 13 to $40 \% .{ }^{9,10}$

A national-level study reported a dose-response relationship of breastfeeding initiation within the first one hour after delivery which was significantly associated with a 3.7 times greater chance of successful exclusive breastfeeding. The likelihood was also found in early initiation after one-hour of delivery, however with a lower odd ratio. ${ }^{10}$ Similar association between both variables was also shown in the district or subdistrict-level analysis. However, other studies refuted this association, ${ }^{11}$ suggesting a mixed-result of the existing evidence.

Although there is growing body evidence of the influence of breastfeeding initiation on exclusive breastfeeding, ${ }^{12,13}$ none has addressed the relationship between both variables among working mothers. In 2017, employed women in Indonesia reached 53\%. ${ }^{1}$ Employment status could be the barrier for working women to provide adequate breastfeeding for their babies due to the short duration of maternity leave. ${ }^{14,15}$ Therefore, our study aimed to analyse the relationship between early initiation of breastfeeding and prevalence of exclusive breastfeeding among employed women in Bantul District, Yogyakarta Special Region, Indonesia.

\section{METHODS}

This study was a part of a larger study titled "Factors associated with exclusive breastfeeding among employed mothers in companies in Bantul District" with one of its findings published elsewhere. ${ }^{16} \mathrm{~A}$ cross-sectional study was conducted in medium - (51 - 200 workers) and large scale (> 200 workers) companies in Bantul District, Yogyakarta Special Region, Indonesia, from December 2016 to March 2017.

Reproductive-age women working at companies in Bantul District with infants aged six to 12 months were included in the study after signed informed consent. Women who did not come to the workplace (e.g., sick leave, paid leave) on the interview day were excluded. We used a probability proportional to size sampling technique in which our cluster was the companies. Finally, our study samples included 158 women from 14 companies spread across Bantul District.

The primary outcome of this study was exclusive breastfeeding, while the main dependent variable was the early initiation of breastfeeding. Early initiation of breastfeeding was a process where the baby was put on the mother's chest during the first one hour immediately after birth. ${ }^{17}$ Other covariates included type of delivery (vaginal or cesarean), preterm birth (if gestational age $<37$ weeks), LBW and breastfeeding counselling during antenatal care visits, and socio-demographic factors. Mothers were considered as having high educational level if they completed at least senior high school. Enumerators consisted of four nutrition students in the fourth year of their study at the Department of Nutrition, Universitas Alma Ata, Indonesia. Two field supervisors with a master degree in public health nutrition assisted in the process of data collection. As many as 158 women who met the 
Table 1. Characteristics of participants and the distribution of main variables

\begin{tabular}{lrr}
\hline Characteristics & \multicolumn{1}{c}{ n } \\
\hline Woman's age & & \\
- $<25$ years & 26 & 16.5 \\
- 25 - 34 years & 106 & 67.0 \\
- > 35 years & 26 & 16.5 \\
First-time mother & & \\
- Yes & 51 & 32.3 \\
- No & 107 & 67.7 \\
Level of education & & \\
- Elementary school & 3 & 1.9 \\
- Junior high school & 52 & 32.9 \\
- Senior high school & 97 & 61.4 \\
- Higher degree & 6 & 3.8 \\
Delivery mode & & \\
- Cesarean & 23 & 14.6 \\
- Vaginal & 135 & 85.4 \\
Received counselling about & & \\
breastfeeding during antenatal \\
care
\end{tabular}

inclusion criteria agreed to participate in the study by completing the informed consent form before the study began.

To describe maternal and child characteristics, we used descriptive statistics. The relationship of each covariate with exclusive breastfeeding was examined using univariate logistic regression. Multiple logistic regression was conducted to analyse all the variables together to find any association with exclusive breastfeeding. We reported both unadjusted and adjusted odds ratios with $95 \%$ confidence interval. All the analyses were performed by using STATA 14.2 at the level significance of 0.05 .
Table 2. Association between early initiation and prevalence of exclusive breastfeeding among employed mothers

\begin{tabular}{|c|c|c|c|c|}
\hline Variables & $\begin{array}{c}\text { Unadjusted } \\
\text { OR } \\
\text { (95\% CI) }\end{array}$ & $\begin{array}{c}\text { p } \\
\text { value }\end{array}$ & $\begin{array}{l}\text { Adjusted } \\
\text { OR } \\
(95 \% \text { CI) }\end{array}$ & $\begin{array}{c}p \\
\text { value }\end{array}$ \\
\hline \multicolumn{5}{|c|}{ First-time mother } \\
\hline - Yes & 1 & & 1 & \\
\hline - No & $\begin{array}{l}2.79 \\
(1.08-7.23)\end{array}$ & $0.04 *$ & $\begin{array}{l}2.27 \\
(0.79-6.51)\end{array}$ & 0.13 \\
\hline \multicolumn{5}{|c|}{ Woman's age } \\
\hline - $<25 \mathrm{yrs}$ & 1 & & 1 & \\
\hline - $25-34$ yrs & $\begin{array}{l}3.90 \\
(0.86- \\
17.63)\end{array}$ & 0.08 & $\begin{array}{l}2.78 \\
(0.51-15.1)\end{array}$ & 0.24 \\
\hline - $>35 \mathrm{yrs}$ & $\begin{array}{l}4.42 \\
(0.82- \\
23.78)\end{array}$ & 0.08 & $\begin{array}{l}3.28 \\
(0.49-22.0)\end{array}$ & 0.22 \\
\hline \multicolumn{5}{|c|}{ Mother's educational level } \\
\hline - Low & 1 & & 1 & \\
\hline - High & $\begin{array}{l}1.22 \\
(0.55-2.68)\end{array}$ & 0.63 & $\begin{array}{l}1.28 \\
(0.55-2.96)\end{array}$ & 0.57 \\
\hline
\end{tabular}

Received counselling about breastfeeding during antenatal care

- No 11

- Yes

$$
\begin{array}{lll}
0.76 & 0.66 & 0.46 \\
(0.23-2.56) & & (0.12-1.76)
\end{array}
$$

Delivery mode

- Vaginal 1

- Cesarean 0.78

$$
\begin{array}{lll}
0.78 & 0.62 & 0.78 \\
(0.29-2.08) & (0.26-2.30)
\end{array}
$$

Early initiation of breastfeeding

- No

$$
1
$$

- Yes

$$
3.17
$$$$
0.03 * 2.93
$$$$
(1.09-9.24)
$$

*level of significance at $p<0.05$

Unadjusted OR: unadjusted odds ratio resulting from univariate logistic regression

Adjusted OR: adjusted odds ratio resulting from multivariate logistic regression

CI: confidence interval

\section{RESULTS}

Characteristics of the study participants are presented in Table 1. The majority of women were aged between 25 and 34 year old $(67.0 \%)$ and completed senior high school education (61.4\%). As many as $88.9 \%$ of women did not initiate 
breastfeeding to their baby and did not provide exclusive breastfeeding (77.8\%). Most women experienced normal delivery mode (85.4\%).

In bivariate results, as shown in table 2, mothers who initiated breastfeeding earlier were three times more likely to be successful in exclusive breastfeeding $(\mathrm{COR}=3.17$; 95\% CI $=1.09$ - 9.24). Moreover, even after adjusting with other covariates, the relationship between breastfeeding early initiation and exclusive breastfeeding remained significant $(\mathrm{AOR}=2.93$; 95\% CI: 1.04 8.28) which means that children who were initiated breastfeeding early after birth had three times greater chance to be breastfed exclusively. On the other hand, variables such as the presence of a firstborn child, maternal age, maternal educational attainment, received breastfeeding counselling during antenatal visits and delivery mode were not significantly associated with exclusive breastfeeding among employed women.

\section{DISCUSSION}

In this study, the coverages of early initiation of breastfeeding and exclusive breastfeeding among mothers in employment were $10.1 \%$ and $22.2 \%$, respectively. These low coverages were in line with the previous analyses among Indonesian women. ${ }^{10}$ Our finding showed that early initiation of breastfeeding was significantly associated with exclusive breastfeeding among employed mothers.

Our results showed that babies receiving breastfeeding initiation were three times more likely to be exclusively breastfed by their mothers. A previous study showed that the chance of being breastfed exclusively was 3.7 times higher if initiated early breast feeding. Similarly, those who received early initiation of breastfeeding even after one hour had the chance of being breastfed exclusively 2.8 times higher. The reason could be that mothers who completed breastfeeding initiation had more confidence and indicated to have family supports which enabled them to any practice that may discard exclusive breastfeeding, such as prelacteal feeding. ${ }^{10}$ Conversely, formula milk sample at the maternity hospital or clinic and lack of family support may lead to the exclusive breastfeeding failure. ${ }^{11}$ Therefore, the initial hour after delivery is a crucial period for providing colostrum and for preventing infections from the harmful prelacteal feeding practice.

In this study, maternal level of education and exclusive breastfeeding were not linked. Our definition of maternal educational attainment covered formal education from schooling which may not represent maternal health knowledge and literacy. Mothers with adequate health knowledge ${ }^{18}$ and literacy ${ }^{19}$ tend to provide exclusive breastfeeding to their babies. Additionally, an earlier study suggested that the father's role may also influence the practice of exclusive breastfeeding through their knowledge and positive attitude towards breastfeeding, as well as their involvement in decision making and emotional and practical support related to breastfeeding. ${ }^{16}$

Receiving counselling about breastfeeding during antenatal care was not related to exclusive breastfeeding practice. In Indonesia, health and nutrition counselling for pregnant women is a part of integrated antenatal care service besides anthropometric measurements, BP check, tetanus vaccine, iron tablet supplementation, biochemical assessment, and examination of fundal height, foetal location and pulse, as well as specific case management. ${ }^{20}$ The topics of counselling might vary from maternal nutrition to breastfeeding. ${ }^{21,22} \mathrm{~A}$ previous study in Indonesia showed that breastfeeding counselling during antenatal care period could increase the practice of breastfeeding. ${ }^{22}$ Nonetheless, delivery of message about the effectiveness of breastfeeding depends highly on the quality of counselling during antenatal care service itself. ${ }^{23}$

The cesarean delivery mode was not associated with exclusive breastfeeding. Studies conducted in Iran $^{24}$ and Nicaragua ${ }^{25}$ also revealed that the type of delivery was not related to exclusive breastfeeding. This could be mediated by the implementation of baby-friendly hospitals which did not allow mothers to be separated from their babies. ${ }^{25}$ The baby-friendly hospital initiative may facilitate exclusive breastfeeding practice through ten steps for successful breastfeeding, including improving the implementation of breastfeeding initiation. ${ }^{26}$ Adherence to these measures not only had a 
positive impact on breastfeeding initiation and exclusive breastfeeding, but also the breastfeeding duration. ${ }^{27}$ For that reason, mothers may still have the opportunity to breastfeed their babies exclusively regardless of the type of delivery.

Special attention is needed for employed mothers as they have limited time and busy activities at work which lead them to not provide breastmilk exclusively to their babies despite their adequate knowledge and understanding about the importance of exclusive breastfeeding. ${ }^{28}$ Besides, the reasons why mothers were not expressing breastmilk at the workplace may include an unsuitable place to express and store the breastmilk and no willingness. ${ }^{29}$ An earlier study in Ghana showed a significant difference in exclusive breastfeeding practice and breastfeeding frequency between women who worked at the formal and non-formal sectors. There was also a difference in frequency of breastfeeding between women who took their babies to the workplace and those who did not. ${ }^{30} \mathrm{It}$ has also been concluded that among working women, family support was also linked with exclusive breastfeeding. This type of support covered emotional, informational, instrumental, and appraisal supports. ${ }^{16}$

Despite its novel findings, this study was limited by the cross-sectional design that did not allow us to draw any causal-effect relationship. This study also lacked in controlling possible covariates such as maternal knowledge, intention, and attitude related to exclusive breastfeeding as well as the place of delivery. Our samples were representative of middle and large scale companies in Bantul District so that to increase the power for hypothesis testing, further study is required to analyse the determinants of exclusive breastfeeding among employed women in other settings.

Finding from this study may provide inputs for either a new policy and program planning or improving existing interventions related to exclusive breastfeeding among working women.

\section{CONCLUSIONS}

Employed mothers with early initiation of breastfeeding are more likely to be successful with exclusive breastfeeding. However, there is no significant relationship between the type of delivery, preterm birth, and low birth weight and exclusive breastfeeding among working women. The initial hour after birth is a critical period for mothers to gain more self-confidence to practice breastfeeding. It is therefore highly recommended to improve early initiation of breastfeeding program to increase exclusive breastfeeding coverage, especially among employed women. This can be achieved by providing adequate education by health providers, support from the family, and regulation and facilities promoting breastfeeding at the workplace.

\section{REFERENCES}

1. National Population and Family Planning Board, Statistics Indonesia, Ministry of Health of Indonesia, ICF. Indonesia demographic and health survey. 2018

2. WHO, UNICEF. Global strategy for infant and young child feeding. 2003

3. WHO. Report of the expert consultation on the optimal duration of exclusive breastfeeding. WHO/NHD/0109. 2001

4. Ministry of Health of Indonesia. Profil kesehatan indonesia tahun. 2016.

5. Paramashanti BA, Hadi H, Gunawan IMA. Pemberian asi eksklusif tidak berhubungan dengan stunting pada anak usia 6-23 bulan di indonesia. IJND. 2015;3(3):162-74. DOI:10.21927/ijnd.2015.3(3).162-174

6. Direktorat Bina Gizi. Pencapaian indikator kinerja pembinaan gizi enam bulanan daerah istimewa yogyakarta. 2015

7. Ministry of Health of Indonesia. Pedoman pekan asi sedunia (pas) tahun 2010: Sepuluh langkah menuju sayang bayi. 2010

8. Becker G, Zisovska E. Evaluation of the baby-friendly hospital initiative in serbia for the period 1995-2008. 2009 
9. NIHRD. Laporan nasional riskesdas 2013 [Internet]. 2013

10. Paramashanti BA, Hadi H, Gunawan IMA. Timely initiation of breastfeeding is associated with the practice of exclusive breastfeeding in indonesia. Asia Pac J Clin Nutr. 2016;25:S52-S6. DOI:10.6133/apjcn.122016.s11

11. Susiloretni KA, Hadi H, Prabandari YS, Soenarto YS, Wilopo SA. What works to improve duration of exclusive breastfeeding: Lessons from the exclusive breastfeeding promotion program in rural indonesia. Matern Child Health J. 2015;19(7):1515-25. DOI:10.1007/s10995-014-1656-Z

12. Walsh SM, Cordes L, McCreary L, Norr KF. Effects of early initiation of breastfeeding on exclusive breastfeeding practices of mothers in rural haiti. JPHCED. 2019;33(5):561-7. DOI:10.1016/j.pedhc.2019.02.010

13. Nakao Y, Moji K, Honda S, Oishi K. Initiation of breastfeeding within 120 minutes after birth is associated with breastfeeding at four months among japanese women: A self-administered questionnaire survey. Int Breastfeed J. 2008;3(1):1. DOI:10.1186/1746-4358-3-1

14. Ogbuanu C, Glover S, Probst J, Liu J, Hussey J. The effect of maternity leave length and time of return to work on breastfeeding. Pediatrics. 2011;127(6):1414-27. DOI:10.1542/peds.2010-0459

15. Rimes KA, Oliveira MICd, Boccolini CS. Maternity leave and exclusive breastfeeding. Rev Saude Publica. 2019; 53. DOI:10.11606/s1518-8787.2019053000244

16. Ratnasari D, Paramashanti B, Hadi H, Yugistyowati A, Astiti D, Nurhayati E. Family support and exclusive breastfeeding among yogyakarta mothers in employment. Asia Pac J Clin Nutr. 2017;26:31-5. DOI:10.6133/apjcn. 062017.s8

17. WHO. Indicators for assessing infant and young child feeding practices: Part1. Definition. Conclusions of a consensus meeting held in 6-8 November 2007 in Washington DC, USA [serial on the Internet]. [Internet]. 2008

18. Sipahutar S, Lubis N, Fazidah S. The association between maternal knowledge, family support, and exclusive breastfeeding in siborong borong community health center, north tapanuli, north sumatera. JMCH. 2019;4:328-31. DOI: 10.26911/thejmch.2019.04.05.06

19. Hoseini F, Rasekhi A, Lamyian M. Factors associated with exclusive breastfeeding among primiparous women. JNE. 2019;8(2):51-7.

20. Dharmayanti I, Azhar K, Tjandrarini D, Hidayangsih P. Pelayanan pemeriksaan kehamilan berkualitas yang dimanfaatkan ibu hamil untuk persiapan persalinan di indonesia. JEK. 2019;18:60-9. DOI:10.22435/jek. 18.1.1777.60-69

21. Subarda S, Hakimi M, Helmyati S. Pelayanan antenatal care dalam pengelolaan anemia berhubungan dengan kepatuhan ibu hamil minum tablet besi. JGKI. 2011;8(1):7. DOI:10.22146/ijcn.17725

22. Nurhayati E, Fikawati S. Counseling of exclusive breastfeeding during antenatal care (anc) and perceptions of insufficient milk supply. IJND. 2019; 7(2): 65-73. DOI:10.21927/ijnd.2019.7(2).65-73

23. Purnamasari SD, Kurniasari Y, Hadi H, Wahyuningsih W, Paramashanti BA, editors. Quality of antenatal care services provided by health workers related to exclusive breastfeeding among yogyakarta mothers in employment: A qualitative study. The Ist International Conference on Health Alma Ata University 2018. Yogyakarta: Elmatera Publishing; 2018.

24. Shariat M, Abedinia N, Noorbala AA, Zebardast J, Moradi S, Shahmohammadian N, et al. Breastfeeding selfefficacy as a predictor of exclusive breastfeeding: A clinical trial. IJN. 2018;9(3):26-34. DOI: 10.22038/ijn. 2018.24694.1316

25. Kiani SN, Rich KM, Herkert D, Safon C, Pérez-Escamilla R. Delivery mode and breastfeeding outcomes among new mothers in nicaragua. Matern Child Nutr. 2018;14(1):e12474. DOI:10.1111/mcn.12474

26. Park HW, Ryu KH, Piao Y, Li P, Hong JS, Kim HB, et al. Positive effect of baby-friendly hospital initiatives on improving mothers' intention for successful breastfeeding in korea. J Korean Med Sci. 2018;33(43):e272-e. DOI: 10.3346/jkms.2018.33.e272

27. Pérez-Escamilla R, Martinez JL, Segura-Pérez S. Impact of the baby-friendly hospital initiative on breastfeeding and child health outcomes: A systematic review. Matern Child Nutr. 2016;12(3):402-17. DOI:10.1111/mcn.12294

28. Dahlan A, Mubin F, Mustika DN. Corelation status to work in exclusive breastfeeding in ward Palebon city district in Pedurungan Semarang. Jur Bid. 2013;2(2):56-60. DOI:10.26714/jk.2.2.2013.56-60 
29. Ratnayake HE, Rowel D. Prevalence of exclusive breastfeeding and barriers for its continuation up to six months in kandy district, Sri lanka. Int Breastfeed J. 2018;13:36-9. DOI:10.1186/s13006-018-0180-y

30. Nkrumah J. Maternal work and exclusive breastfeeding practice: A community based cross-sectional study in efutu municipal, Ghana. Int Breastfeed J. 2017;12(1):10. DOI:10.1186/s13006-017-0100-6 